\title{
Materials with potentially bioactive properties - preparation and characterization of electrospun poly(vinyl alcohol)/beeswax fiber web
}

\begin{abstract}
Currently is observed a great interest in the use of bioactive natural products for modification and functionalization of fibers to produce antimicrobial protective medical textiles. One of the areas is related to the ability to obtain electrospun nanofibers with potential bioactive properties. The aim of this study was to produce and characterize nanofibers from an aqueous solution of poly (vinyl alcohol (PVA) and beeswax (BW). To investigate the possibility of obtaining nanofibers with addition of beeswax is done in two forms - as solution and micro emulsion. Beeswax has a rich chemical composition, a mixture of proteins, vitamins, trace elements, esters, fatty acids, carbohydrates, lipids. Itself smoothies and moisturizes the skin, helps in the treatment recovery of burned skin, slows aging and has antibacterial activity.
\end{abstract}

The fibers were produced in laboratory conditions with single nozzle spin-draw device. The nanofibers are based on 9\% PVA solution and 2\% (by weight) beeswax as additive. s a pad for the electrospun nanofibers has been used thermobonded medical nonwoven textile. The structure of the nanofiber layers is investigated by scanning electron microscope (SEM) and atom force microscope (AFM). The fabrication of poly (vinyl alcohol) non-woven materials by electrospinning of polymer solutions, containing various concentrations of cationic, anionic amphoteric and nonionic surfactants is a complicated process. The type of additive which is used for the functionalization of the fibers changes an electroconductivity, surface tension, viscosity, therefore rheological method for controlling the process was used. The properties of the electrospun materials like air permeability, water vapor permeability, mass and thickness are examined as well. The average diameters of the produced bicomponent fibers were in the range 100-420 nm. Water-resistant nanofibrous materials were obtained by thermal crosslinking at $100^{\circ} \mathrm{C}$ for $12 \mathrm{~h}$. Fourier transformed infrared spectroscopy (FTIR) showed that PVA/BW nanofibers are present in a stable form.

A further project employs to examine the received bilayer material to determine their biological activity and their potential use as plasters for regeneration of skin injuries.

Keyword: PVA/BW, nanofibers, produce, characterize, water-resistant, FTIR, biological activity

\section{INTRODUCTION}

Medical textiles represent structures designed and accomplished for a medical application. The number of applications is diverse, ranging from a single threaded structure to complex composite structures for bone replacement and from a simple cleaning wipe to advanced barrier fabrics used in operating rooms.

Textile materials and products, are suitable for any medical and surgical application where a combination of strength, flexibility and sometimes moisture and air permeability is required.

Significant step forward in the production of bandages for regenerative medicine is the use of new technologies and the production of innovative products that are flexible, with certain specific permeability and mechanical strength. The most used for this purpose are the functionalized nonwovens. The patches with their participation are protected from secondary infection and other external influences, such as drying of the wound, stopping the bleeding and regeneration.

Author's address: ${ }^{1}$ Mechanical Technology Faculty, ${ }^{2}$ Faculty of power engineering, Technical University - Sofia, Bulgaria

Paper received: 18.02.2015.

Paper accepted: 06.04.2015.
Nonwoven materials are increasingly popular in medical applications because they can be:

- made sterile, via one of the methods of sterilization, without changing their properties;

- anti-microbial;

- $\quad$ soft and stretchable;

- with a certain liquid repellent or liquid absorbent;

- $\quad$ with a good capillary activity and wetting;

- neutral in respect of human body;

- with a certain percentage of moisture.

Most nonwovens used outside of the body are disposable, single-use products that don't require sterilization or cleaning for re-use. Disposable nonwovens are manufactured, sterilized, packaged, opened, used and then disposed off, with less risk of contamination before and after use than a reusable product. New products and biotechnological advancements are competing in a fast track market that seeks to improve the quality of life for millions of individuals.

To date, most tissue engineering studies are focused on the investigations of macrolevel structures (e.g., supercelluar structures $>100 \mu \mathrm{m}$ and cellular structures $>10 \mu \mathrm{m}$ ) to build the essential gross morphology. However, to ultimately engineer 
the functional units of the tissue, not only the supercelluar and cellular scale structures but also the subcellular scale structures $(0.1-10 \mu \mathrm{m})$ and nanostructures $(1-100 \mathrm{~nm})$ need to be constructed to control cellular environment, cell-molecular interactions, and cell-cell interactions.

Inactive or conventional wound dressings cover the wound with passive absorption of exudation which provide limited protection. They are made of cotton (gauze compresses), synthetic fibers (nonwovens) or several layers of material (wound gauzes).

The advantage of these dressings is their absorbency and low cost. Disadvantages are the possible desiccation of the wound and adhesion to the wound bed. Fresh granulation tissue is then destroyed on changing dressings and is also very painful for the patient.

Normally they are built from several layers:

a) Wound contact layer: It should not stick to the wound or cause maceration of the skin if the dressing is not changed. It can be woven, knitted or non-woven made from silk, viscose, polyamide or polyethylene.

(b) Middle absorbing layer: - If has to absorb blood or liquids while providing a cushioning effect to protect the wound. It is generally a non-woven composed of cotton or viscose.

(c) Base Material: It provides a means by which the dressing is applied to the wound. The material is coated with acrylic adhesive to hold the dressing in place.

Inside layer: between wound and wound dressings exist various forms of interaction, because of special material properties enter into interaction with the wound, such as the absorption exudation and toxic substances, allowing gas exchange, so as to create an ideal healing environment (fig.1).

For the construction of each of these layers may be used natural materials as plants (cotton, alginate), animal (chitin, collagen) or synthetic fibers. Synthetic materials category can be films, hydrogels, hydrocolloid or foam.

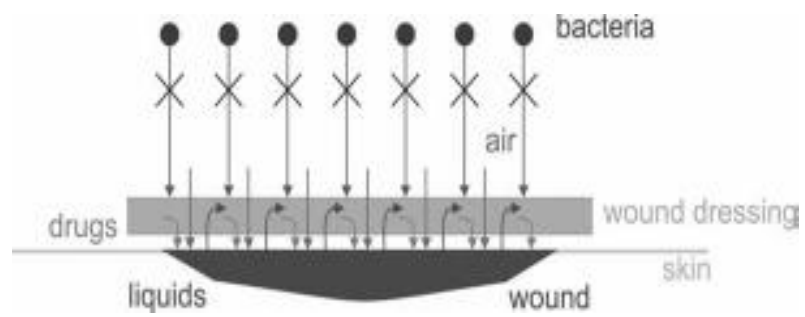

Figure 1 - A wound dressing functionality [1]

This layer barrier protect from the invasion of microorganisms in the environment, prevention of wound infection, etc.
Nonwovens can be made of natural materials, such as cotton, linen, wood pulp, and paper, or man-made materials such as polyester, polypropylene, polyimide, and polytetrafluoroethylene (PTFE). New biopolymer materials such as polylactide (PLA) are also starting to see use as renewable and biodegradable/recyclable options to synthetic fibers. Synthetic nonwovens are lint-free, pure, and more cost-effective in many cases than natural materials. With synthetic nonwovens, various parameters can be easily controlled, including:

- Porosity

- Weight

- Thickness

For many years poly vinyl alcohol (PVA) has been known as a versatile and valuable fibers forming polymer, which is widely used to create a variety of products including nonwoven webs. It is a synthetic, biocompatible and toxicologically safe polymer that is exceptionally well suited for a variety of pharmaceutical applications: In tablet coatings, for example, it protects the tablet from environmental humidity, in eye drops - it moistens the eye, and in cell fermentation processes. Polyvinyl Alcohol prevents bubble rupture to protect cells from shearing. Thanks to profitable properties, its excellent biocompatibility and mechanical properties, the bio-medical application of polyvinyl alcohol-hydrogels (PVA) in various fields have been under study for a long time. Poly (vinyl alcohol) (PVA) is one of the most popular polymers used as a raw material for nanofibres production via electrospinning because it has excellent film forming, emulsifying and adhesive properties. It is commonly processed from water solutions. Water insoluble PVA nanofibres are obtained using a crosslinking, most often by heat treatment. The crosslinks, either physical or chemical, provide the structural stability needs after it swells in the presence of water or biological fluids. The degree of crosslinking dictates the amount of fluid uptake, and thus the physical, chemical, and diffusional properties of the polymer, and ultimately its biological properties [2].

PVA electrospinning process and its throughput can be influenced by various additives. For years different efforts have been undertaken to improve PVA fibers properties and to functionalize it. The most common technique consists on the application of electrospinning with additives, which are incorporated into the fibres during their formation [3-5]. Additives are usually added in the form of solution or dispersion, which are mixed with the polymer solution and then homogenized.

Electrospinning technology is a simple and lowcost method for making ultrathin diameter fibers. Electrospinning method, patented in 1934 
(Formhals), proposed the use of electrostatic forces to form the polymer filaments. Under the applied electrostatic force, the polymer is ejected from the nozzle, whose diameter is reduced significantly as it is transported to and deposited on a collector, which also serves as the ground for the electrical charges. Recently, the ultrafine fiber webs prepared by the electrospinning process have been extensively studied because of their unique properties such as high surface area-tovolume ratio, small pore sizes, high porosity, and so on. In particular,the incorporation of therapeutic compounds into the electrospun nanofibers has attracted a great deal of attention, because the resultant nanofiber webs have very strong efficacy of the drug due to their high surface area-to-volume ratio [6].

Still list and other methods that may be able in the future to find a practical application, if overcome technical and economic disadvantages of them, the method of extraction, "template" synthesis, phase separation, self-organizing associations, split table bicomponent fibers. Electrospinning method is superior to all others on the most important technical and economic indicators: the possibility of industrial production, reproducibility of properties, facilities technology, control over the fineness of fibers, cheap technology, the ability to use a wide range of fiber-forming polymers, availability and adaptability of solvents.

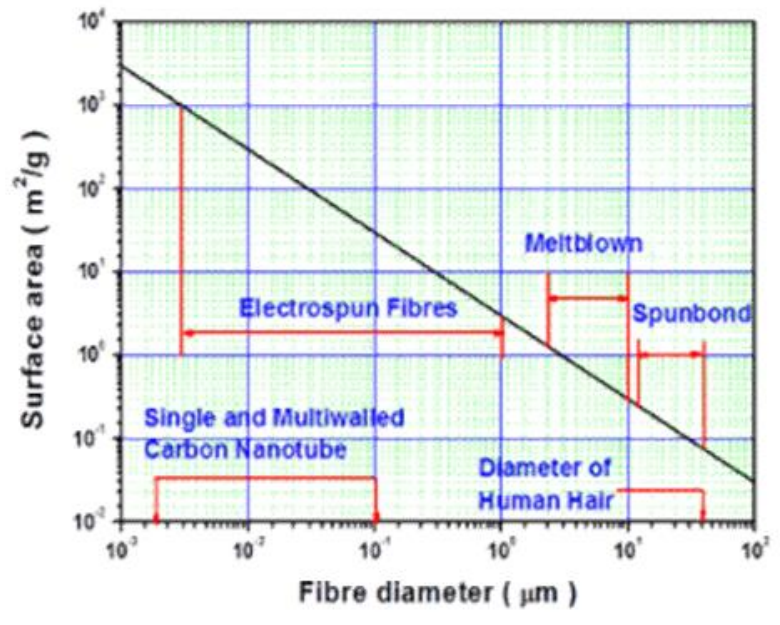

Figure 2 - Place of electrospinning process between modern technology to produce nonwovens [7]

In Figure 2 is shown place of electrospinning process between modern technology to produce nonwovens.

The aim of our work in recent years is to produce nanofibers with potential bioactive and wellness properties by adding beeswax in two forms - as solution and micro emulsion. Beeswax is a tough wax formed from a mixture of several compounds as: Hydrocarbons- $14 \%$; Monoesters35\%; Diesters-14\%; Triesters -3\%; Hydroxy monoesters -4\%; Hydroxy polyesters - 8\%; Acid esters $1 \%$; Acid polyesters $-2 \%$; Free fatty acids $-12 \%$; Free fatty alcohols $-1 \%$; Unidentified-6\%. An approximate chemical formula for beeswax is $\mathrm{C}_{15} \mathrm{H}_{31} \mathrm{COOC}_{30} \mathrm{H}_{61}$ Its main components are palmitate, palmitoleate, and oleate esters of longchain (30-32 carbons) aliphatic alcohols, with the ratio of triacontanyl palmitate $\mathrm{CH}_{3}\left(\mathrm{CH}_{2}\right)_{29} \mathrm{O}-\mathrm{CO}$ $\left(\mathrm{CH}_{2}\right)_{14} \mathrm{CH}_{3}$ to cerotic acid $\mathrm{CH}_{3}\left(\mathrm{CH}_{2}\right)_{24} \mathrm{COOH}$, the two principal components, being 6:1. Beeswax can be classified generally into European and Oriental types. The saponification value is lower (3-5) for European beeswax, and higher (8-9) for Oriental types.

\section{EXPERIMENTAL}

Laboratory apparatus for electrospinning used, is made in the Technical University of Sofia and consists of a high voltage power supply with positive and negative polarity, a needle spinneret which is connected to the syringe with a polymer reservoir and a conducting flat plate or rotating drum which acts as a ground collector (Fig.3).

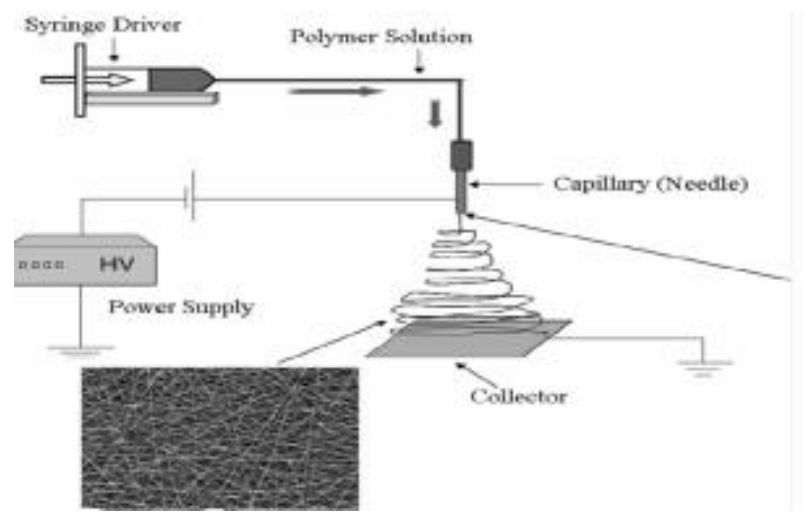

Figure 3 - Electrospinning apparatus

It is possible to heat the polymer solution up to a temperature of $80{ }^{\circ} \mathrm{C}$. Over the conductive collector are used different types of textile materials - Denim fabric, thermal bonded and obtained by the wet method nonwoven pads, special membranes. They all have different surface finish, porosity and adhesion to the polymer. In this work we present only the results obtained by applying layers of nanofibers on thermobonded nonwoven material from $100 \%$ PET (common polyester fibers are hydrophobic in nature), weighing: $30 \mathrm{~g} / \mathrm{m}^{2}$. The whole electrospinning setup is placed in a plexiglass box that helps to limit the exposure of the whole system to the exterior. This box helps in isolating the electro spinning process from unpredictable parameters that can alter the fibers production process. The syringe is driven by a 
syringe pump which is used to control the flow rate and volume of the polymer being ejected.

The polymer solution is held by its surface tension in the form of a droplet at the needle tip (spinneret). When an electric potential is applied between the needle of the syringe and the collector, with increasing the voltage, charge is induced on the fluid surface and the pendant droplet of the polymer solution at the needle tip is deformed into a conical shape (Taylor cone). This occurs at the equilibrium of the electric forces and surface tension of the polymer solution. When the intensity of the electrical fields surpasses a critical value, the electrostatic force will increase the electrical repulsion between the mutual charges and will overcome the surface tension of the polymer solution and consequently, a fine charged jet is ejected from the apex of the cone. Meanwhile, the solvent starts immediately to evaporate and finally the jet solidifies into fibers deposited on the collector plate.

The main technological parameters are:

a. Polymer solution parameters - Molecular weight and solution viscosity; Surface tension; Solution conductivity; Dielectric effect of solvent.

b. Processing parameters - Voltage; Feed rate; Temperature; Effect of collector; Diameter of the orifice of the needle, Distance between the tip of the needle and the collector.

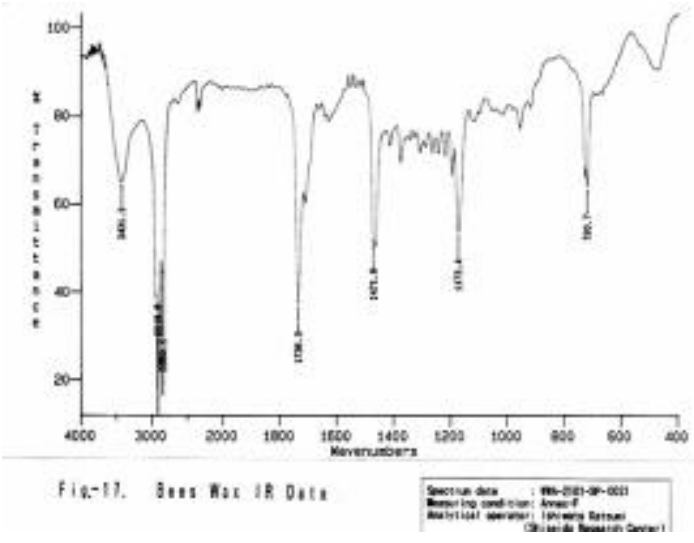

a)

Figure 4 - he IR spectrum of Bee wax and PVA/Bee wax

To obtain a solution from the hard natural product, is the beeswax has been chopped into small pieces and mixed a monoterpene in ether. The solvent was poured into the PVA solution in small portions and stir thoroughly. Volume of solution used for electrospinning of nanofibers from PVA and additives was $10 \mathrm{ml}$ by flow rate $5.5 \times 10^{-4}$ $\mathrm{cm}^{3} / \mathrm{sec}$.

The process parameters are given in table 1.

This is due to altered properties of the solutions after the addition. It is necessary to change the distance between the nozzle and the collector, the
Usual experimental procedure is as follows:

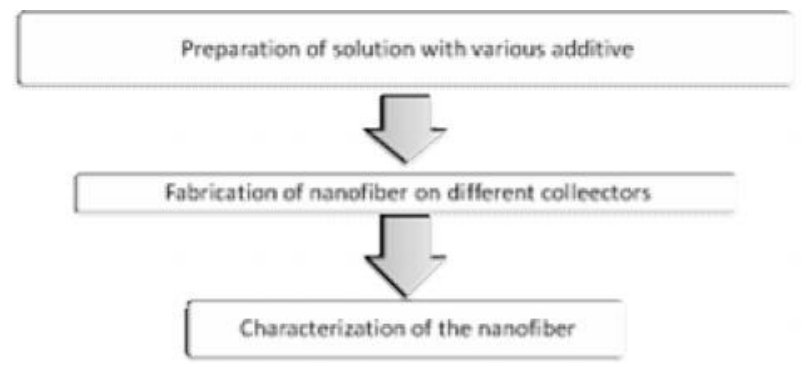

A solution is prepared from PVA with molecular weight (Mw) 85000 (Merck), and after digesting is mixed with distilled water. The used concentration of PVA is $9 \% \mathrm{w} / \mathrm{v}$. The additive of Beeswax (BW) in two form was used to change properties of PVA solutions - as solution of natural beeswax after purification (PVA-BW) and NouWell BEE from Bezema - (PVA-BEE) - a mixture of natural beeswax and polyethylene wax, nonionic, weakly alkaline macroemulsions. This product has natural properties of the beeswax.

The concentration of the additive of $2 \%$ compared to the dry matter of PVA is added to the PVA viscous aqueous solution. The magnetic stirrer at $80^{\circ} \mathrm{C}$ for 7-8 hours are used, obtain proper mixing of the components. Then the solution was filtered through a glass filter G2 under vacuum. Figure 4 shows infrared spectra of the used wax (a) and wax mixture PVA- bee wax (b).

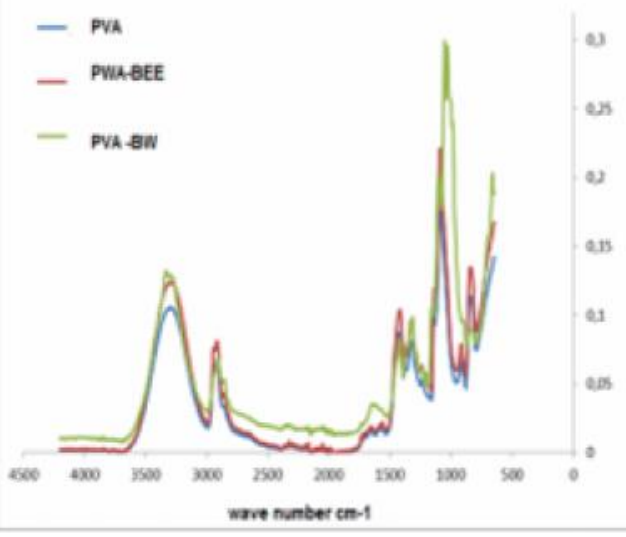
b)

applied voltage, the temperature in a container with a solution and the nozzle size.

Table 1 - Clearly shows the change in the electrospinning process parameters that are necessary to produce nanofibers in the participation of additives

\begin{tabular}{|l|c|c|c|c|}
\hline Sample & $\begin{array}{c}\text { Applied } \\
\text { voltage } \\
{[\mathrm{kV}]}\end{array}$ & $\begin{array}{c}\text { Tip to colle } \\
\text { ctor distance } \\
{[\mathrm{cm}]}\end{array}$ & $\begin{array}{c}\mathrm{T} \\
{ }^{\mathrm{T}} \mathrm{C}\end{array}$ & $\begin{array}{c}\text { Syringe } \\
\text { dimension } \\
{[\mathrm{mm}]}\end{array}$ \\
\hline PVA & 30 & 17 & 22 & 0.5 \\
\hline PVA BW & 30 & 14,5 & 60 & 0.7 \\
\hline PVA BEE & 30 & 16 & 40 & 0,7 \\
\hline
\end{tabular}


On one hand this is due to increased working temperature of the solution in the presence of additives and on the other due to changed properties of the viscous polymer solution. These changes can be seen from the results presented in Figures 5,6,7.

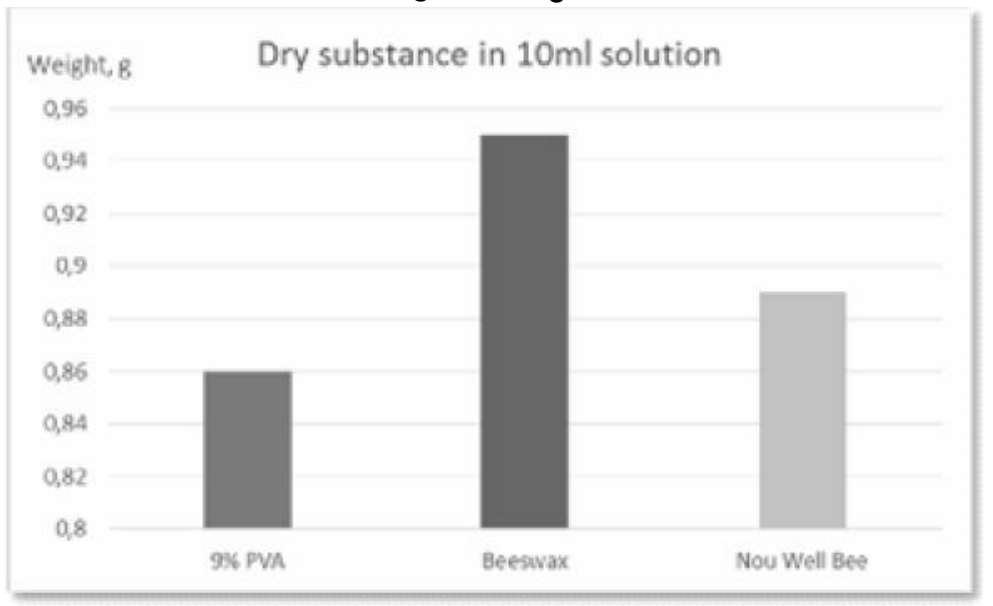

Figure 5 - Dry substance in solution after addition of both products

Quite logical the amount of dry matter changes after the addition of the two products.

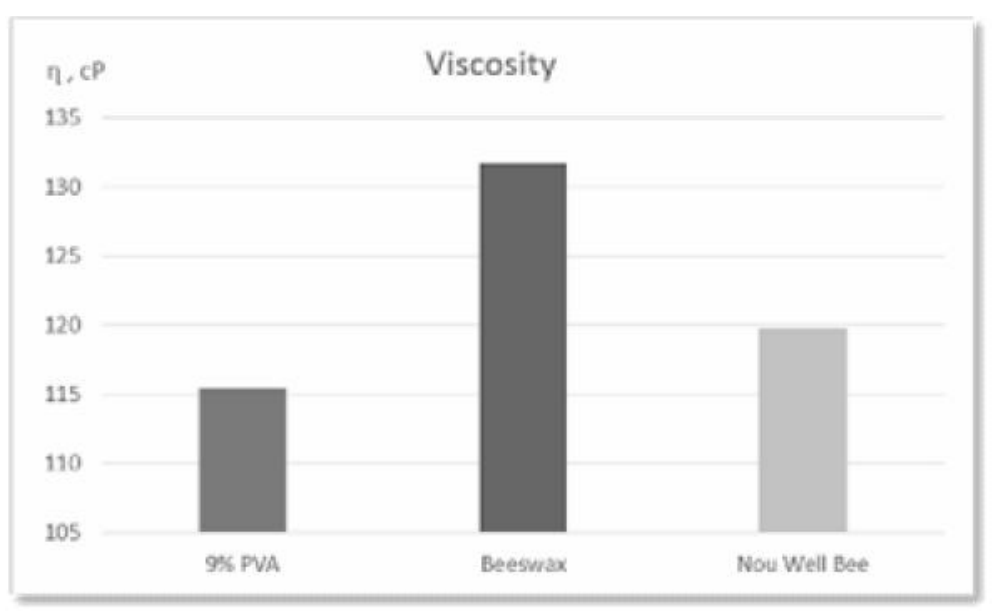

Figure 6 - Viscosity of the solution after addition of both products

Changes in viscosity impose adjustments to the process parameters, compared to those when working with pure PVA, in order to provide uniform delivery of the solution from the syringe. According to studies of A. Kowalewski, A. L. Yarin \& S. Błoński [8], generally in the choice of electrospinning parameters is the change of the conductivity of the solution.

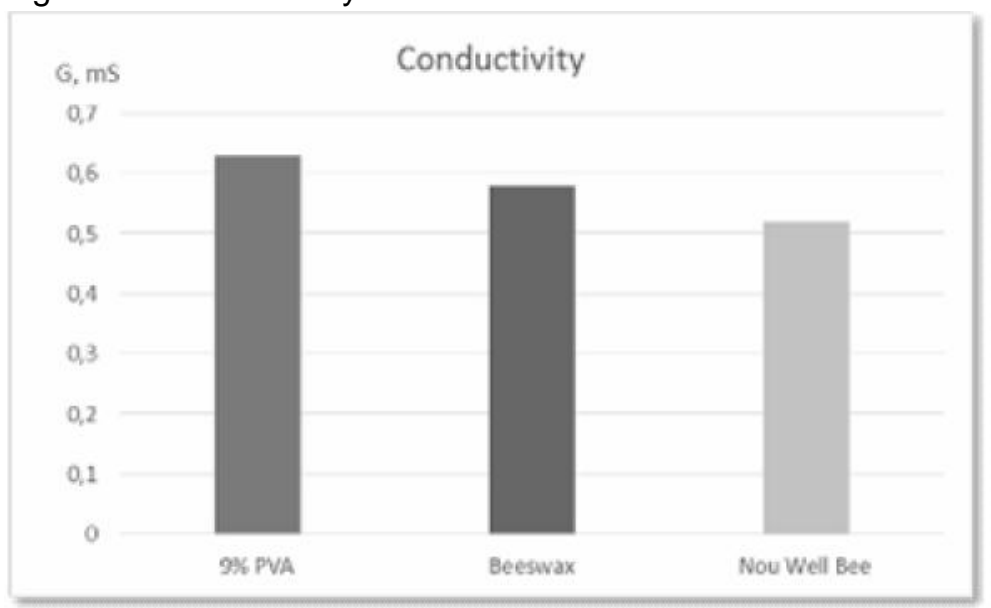

Figure 7 - Influence of the type of the additive on the conductivity of the solution 
This is because the moving charges (ions) interacting with electrostatic field amplify bending instability, surface tension and viscoelasticity counteract these forces. The growth rate of the spiral diameter (envelope of the cone) depends on the electrical potential and fluid properties. Due to the electrical forces and stretching the fluid is accelerated reaching velocity of several $\mathrm{m} / \mathrm{s}$ by vector $F_{1}$ (fig.8) Parallel with this, the evaporation of solvent, in this case - water is executed.

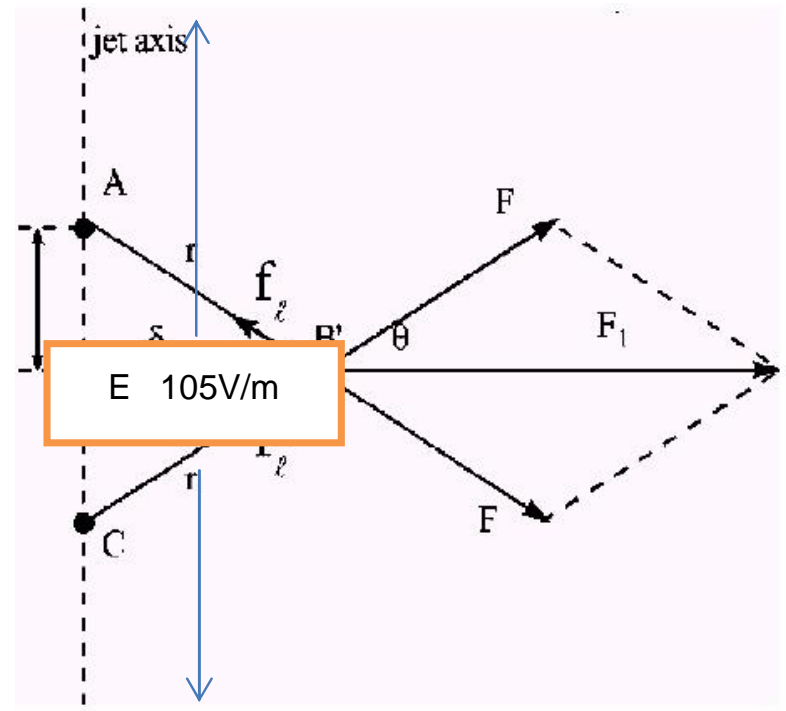

Figure 8 - Schematic presentation of the forces in the camera for electrospinning
It is interesting to note that while the additive solution viscosity increases due to an increase in the amount of dry substance, and the electrical conductivity decreases. The influence of the additive is stronger using the obtained solutions.

It is known that under DC voltage, ions inside polymer solutions move toward an electrode. Therefore, the amount of ion reduction, the change of electrical conductivity and surface tension resistance of the polymer solutions cause a change in the current of the circuit. When using the two additives, the viscosity of the solution increases, to a greater extent by using bee wax in pure form, against a pure PVA solution, but conductivity decreases. Process parameters of electrospinning, depend on how strongly a material opposes the flow of electric current. In this case the viscosity increases but the conductivity decreases and thus vary the distance between the two electrodes. The additives modify the surface tension of the droplet. Surface tension, as the function of solvent compositions of the solution is quite important factor in electrospinning. With the concentration fixed, reducing the surface tension of the solution, beaded fibers can be converted into smooth fibers. Additionally, the surface tension and solution viscosity can been adjusted with various additives. Basically, surface tension determines the upper and lower boundaries of the electrospinning window if all other conditions are fixed [9-11].

The volume of the droplet and the obtained values by the pendant drop method are shown in Table 2.

Table 2 - The volume of the droplet and the obtained values by the pendant drop method

\begin{tabular}{|c|c|c|c|c|}
\hline Sample & Electric conductivity $(\mathrm{mS})$ & Average diameter, $(\mathrm{m})$ & $\begin{array}{c}\text { Surface Tension, } \\
(\mathrm{mN} / \mathrm{m})\end{array}$ & Viscosity, (mPa.s) \\
\hline PVA & 0.63 & 0,32 & 53,0 & 115,4 \\
\hline PVA BW & 0.58 & 0,74 & 44,8 & 131,7 \\
\hline PVA BEE & 0.52 & 0,52 & 48,5 & 119,8 \\
\hline
\end{tabular}

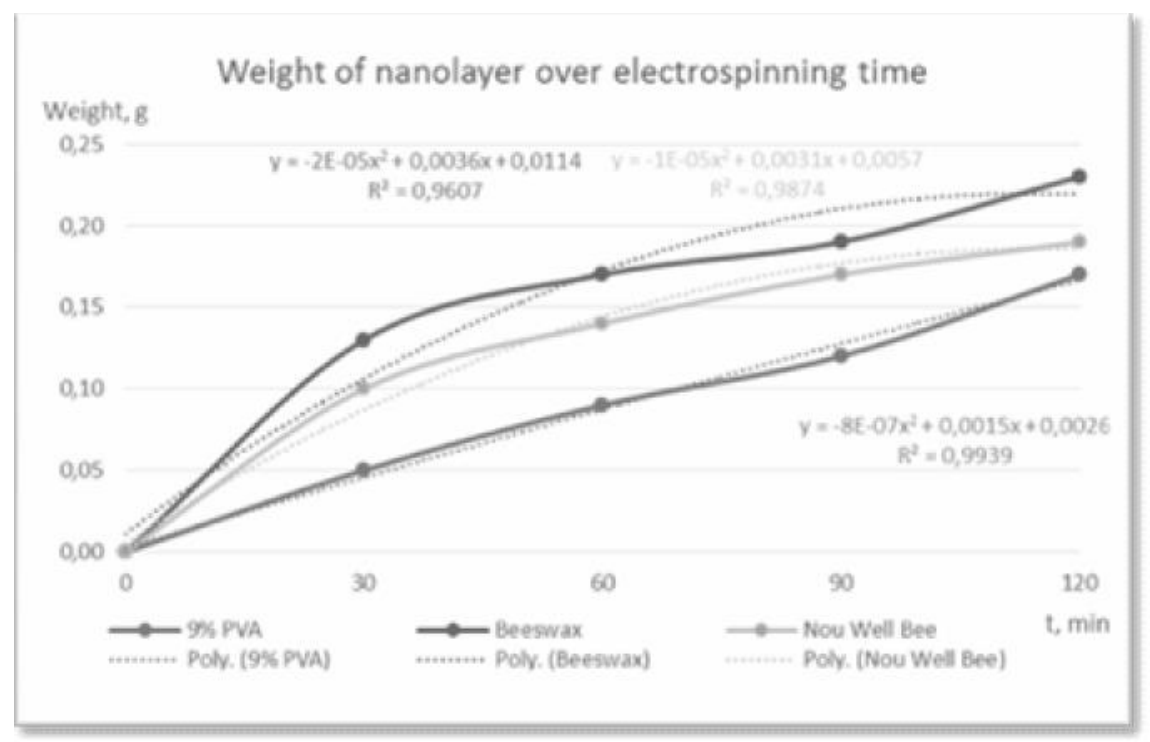

Figure 9 - Kinetics of growth of the mass of nanofibers 
If the jet of PVA solution increases more slowly due to the difference in the parameters of the solutions with the addition, the solution needs longer time to be split in somparison with PVA-BW and PVA-BEE. This is reflected with the increase in mass of the layer of nanofibres, shown in figure 9.

The rate of growth of the mass of nanofibers is higher in the presence of the additive of pure bee wax. This is possibly due to the action also as a plasticizer. In both cases studied, additives such as waxes, accelerate the process of electrospinning and the quantity applied on the collector in just one step increases.

The collected web is usually irregular in form, but by proper adjustment of the collector and the jet loop inclination it is possible to obtain relatively regular, mesh.

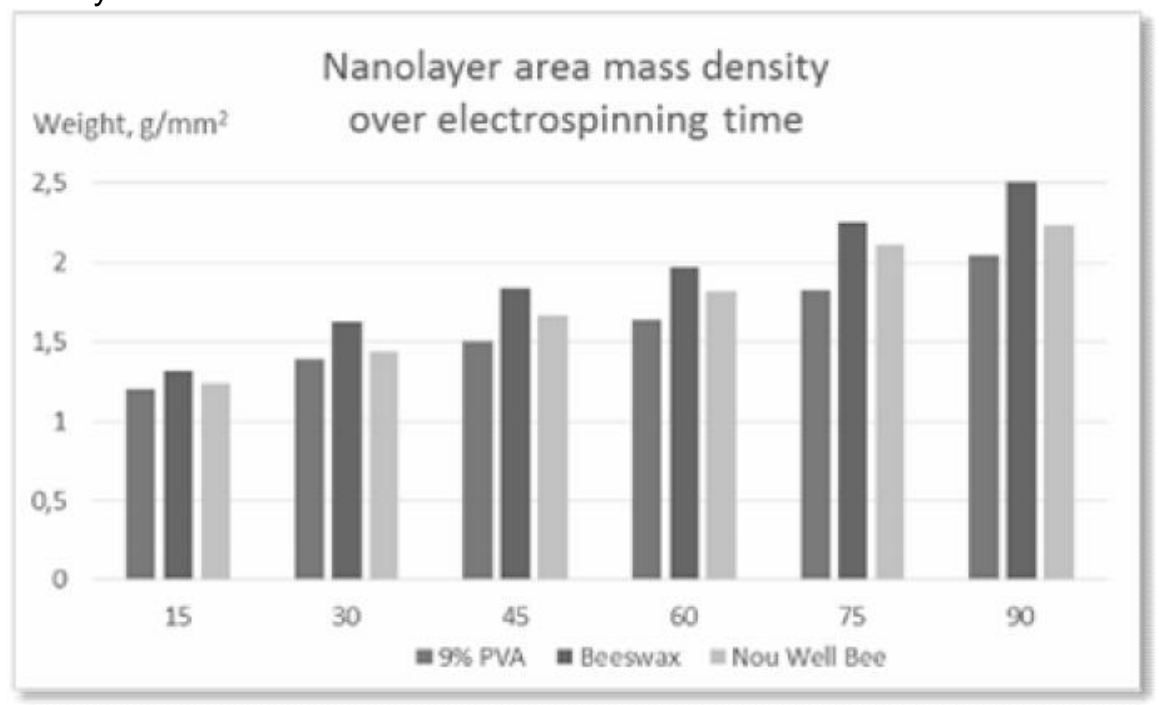

Figure 10 - Increase of the mass of mesh of nanofibers with the duration of electrospinning process

The density of the layer, and its thickness is greater in the presence of a solution of natural beeswax. This is possibly due to the increase of the dry substance, as shown in fig. 11.

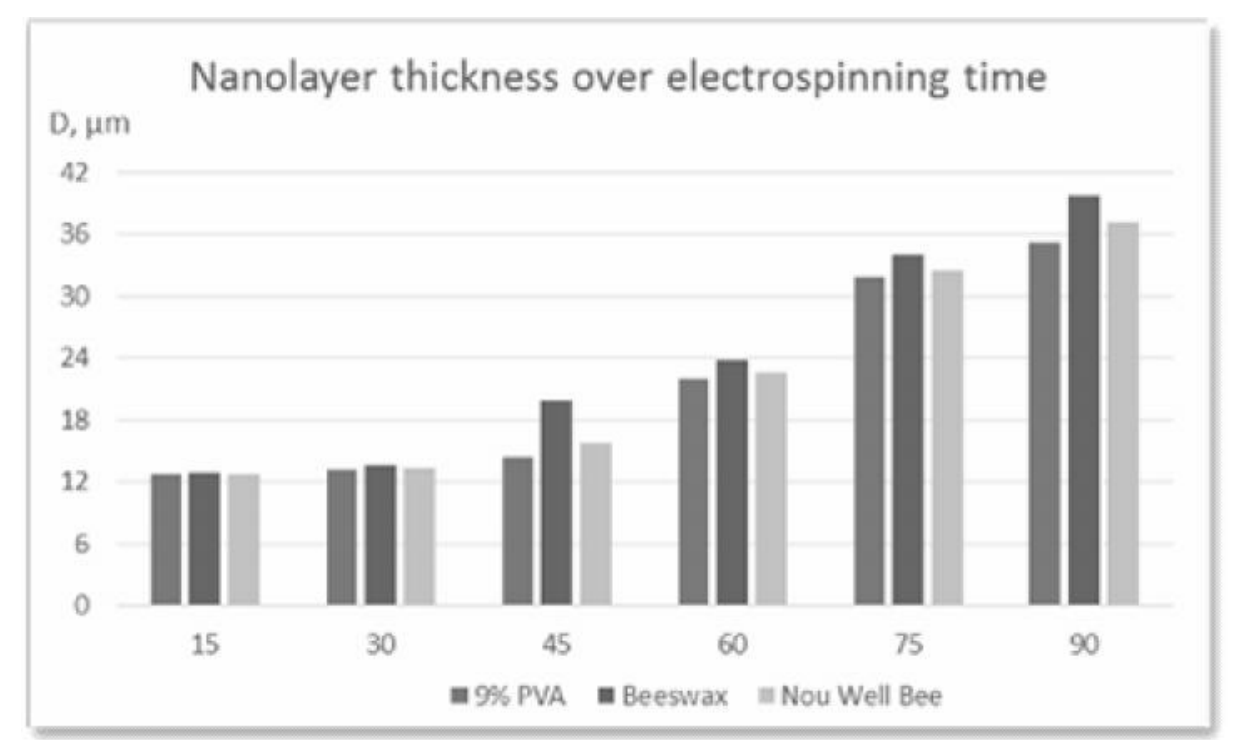

Figure 11 - Increase of the nanolayer thickness with the duration of electrospinning process

The layer thickness is determined using CLSM KEYENCE VK 9710K -Institute of nano and optical technologies to Hochschule Niederrhein, Krefeld, Germany, without separation of the layer from the colector ( fig.12). 

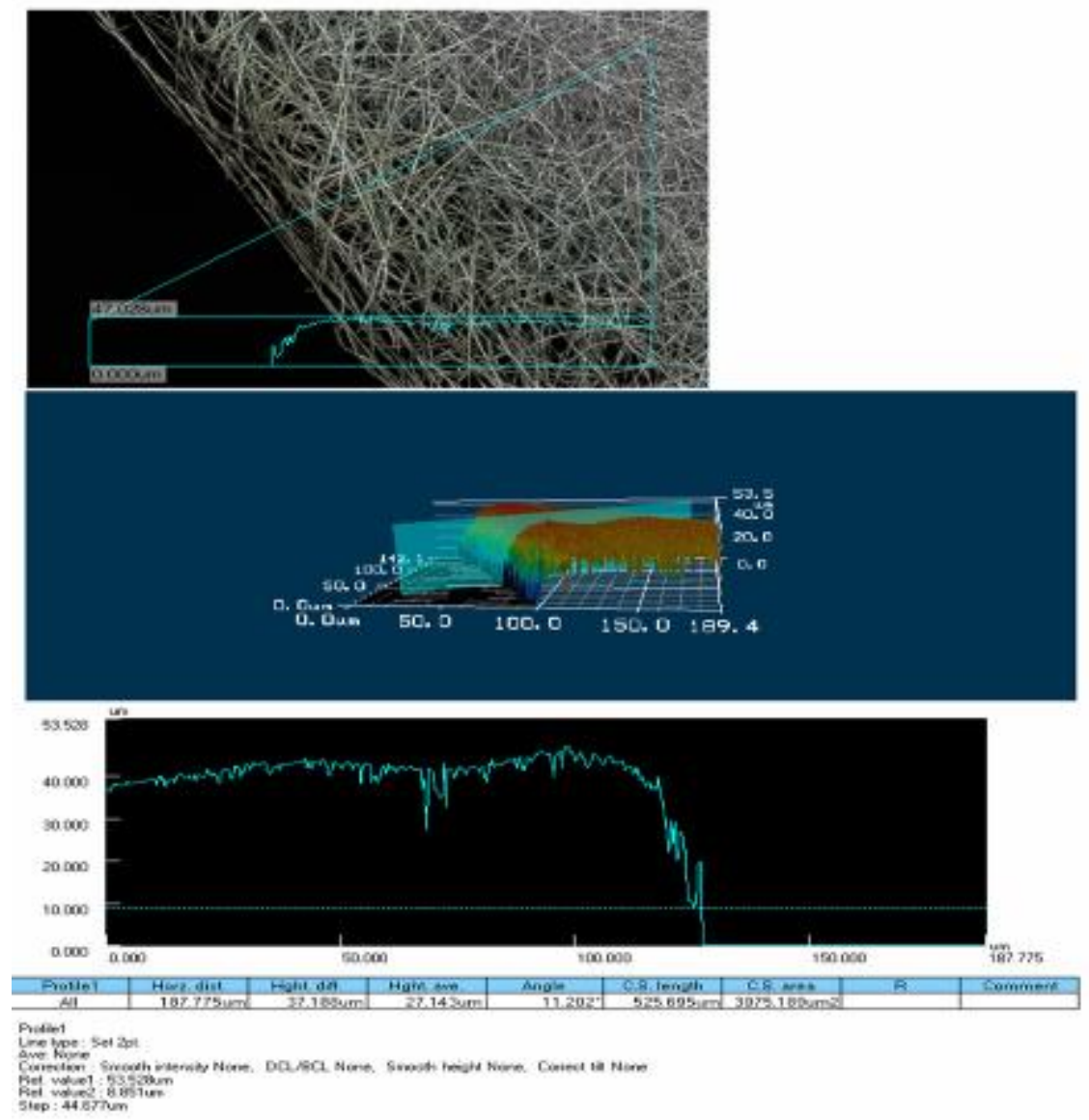

Figure12 - Data obtained by CLSM measuring of the thickness of nano layer

Confocal laser - scanning microscope (CLSM) KEYENCE VK 9710K was used to determine the diameter of the nanofibers. Measured are the diameters of the 20 fibers of the central part (figure 13).
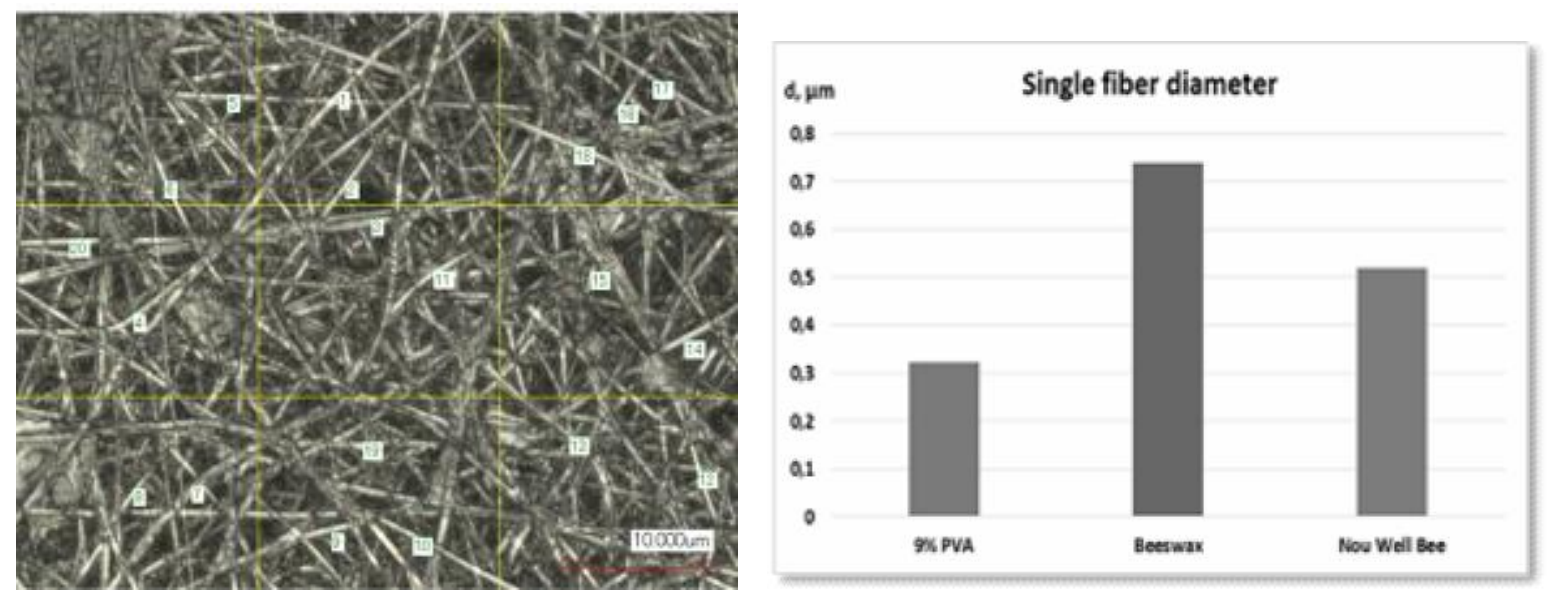

Figure13 - Determination of the average diameter of the fibers

After statistical treatment of results the average diameter of the fibers is as follows:

PVA - $326+/-0,2 \mathrm{~nm} ; \max 455 \mathrm{~nm} ; \min 230 \mathrm{~nm}$

PVA + BW - $325+/-0,3 \mathrm{~nm} ; \max 453 \mathrm{~nm} ; 166 \mathrm{~nm}$

PVA + BEE - $432+/-0,3) \mathrm{nm}$; $\max 679 \mathrm{~nm} ; 276 \mathrm{~nm}$

SEM picture of the fibers obtained are shown in Figure 14. 


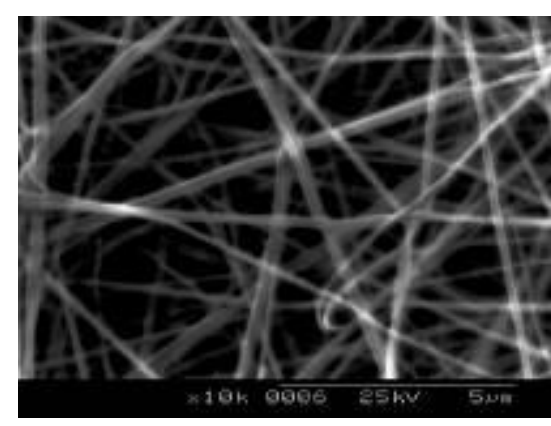

a. PVA

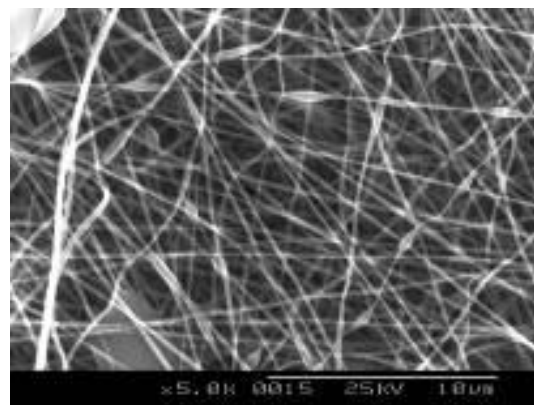

b. PVA-BW

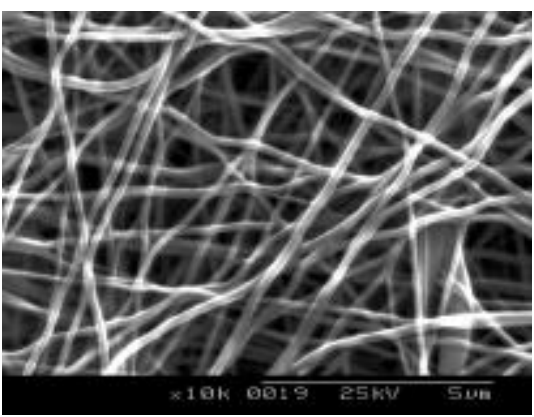

c. PVA-BEE

Figure 14 - SEM pictures of products a: PVA; $b$ : PVA BW; c: PVA BEE

From the obtained values we can see that the average fiber diameter from the three solutions are different. PVA BEE has greater average fiber diameter. In the fibers with the addition of native wax are observed a large number of defects in the form of a spindle, but this is not of a great importance to the selected usage as skin regenerator.

It has been known that after splitting, one jet will be separated into many smaller parts. Sizes of these parts are different. In the same conditions, with shorter length of jet, it also means the diameter of jet is bigger and the average sizes of them are also bigger. Another effect is that, with higher amount of ions, the electric force is higher. It causes more intensive elongation process and smaller fiber diameters. So even these three solutions have some difference in amount of ions, they still have a little difference in average diameter. The additive of bee wax in two form , affect to surface tension and rheological properties of PVA as platizer but not by ther electrical properties. After putting them in to PVA solution, conductivity of solution decreases a little and this is reflected in the determination of the optimal process parameters.

\section{CONCLUSION}

Nanofibers are produced with the participation of beeswax in two forms - a natural product as a solution and as an emulsion of paraffin waxes.

The additives modify the parameters of the process due to the change of the properties of the solution of PVA.

After putting of BW in to PVA solution,change the surface tension, viscosity, conductivity, but this is likely to act as plasticizers downloading fibers.

Additives affect folded on the diameter of the fibers, their distribution and on the rate of electrospinning process.

Although preliminary, results indicate the bioactive effect of the resulting nanonastil.

GRATITUDE: All of the studies in the current paper were carried out and funded through contract № 142 0034-02.

\section{REFERENCE}

[1] By Song (2003) Outside Medical Textile focus on wound dressing, Wiley Periodicals, Inc. J Biomed Mater Res Part B: Appl Biomater, 67B, 675-679;

[2] Alves MH, Jensen BE, Smith AA, Zelikin AN (2011) Poly(vinyl alcohol) physical hydrogels: New vista on a long serving biomaterial. Macromol Biosci 11, 5,1293-1313;

[3] D.Lukas, A. Sarkar, L. Martinova, K. Vodsed'alkova, D. Lubasova (2009) Physical principles of elctrospinning, Textile Progress Vol. 41, No.2, ;

[4] S. Ramakrishna, K. Fujihara, W. Teo, T. Lim, and Z. Ma (2005) An introduction to electrospinning and nanofibres, World Scientific Publishing Co., Singapor;

[5] Anthony L.Andrady (2008) Science and Technology of Polymer Nanofibers; John Wiley \& Sons, Inc.,Hoboken, New Jersey;

[6] E.R. Kenawy, G.L. Bowlin, K. Mansfield, J. Layman, D.G. Simpson, E.H. Sanders, and G.E. Wenk, J. Controlled.Release., 81, 57 (2002);

[7] Umney, Nick; Shayne Rivers (2003). Conservation of Furniture. Butterworth-Heinemann. p. 164.

[8] T. A. Kowalewski, A. L. Yarin \& S. Błoński, NANOFIBRES EFMC 2003, Toulouse.

[9] Haghi AK, Akbari M (2007) Trends in electrospinning of natural nanofibers. Phys Status Solidi (a) 204(6):1830-1834. doi:10.1002/pssa.200675301;

[10] Pham QP, Sharma U, Mikos AG (2006) Electrospun Poly(e-caprolactone) Microfiber and Multilayer Nanofiber/Microfiber Scaffolds: Characterization of Scaffolds and Measurement of Cellular Infiltration. Biomacromolecules 7(10),2796-2805. doi:10.1021/ bm060680j References 2718;

[11] Zhang C, Yuan X, Wu L, Han Y, Sheng J (2005) Study on morphology of electrospun poly(vinyl alcohol) mats, Eur.Polym.J. 41(3),423-432. doi:10.1016/j.eurpolymj.2004.10.027]. 


\title{
IZVOD
}

\author{
MATERIJALI SA POTENCIJALNO BIOAKTIVNIM SVOJSTVIMA - SINTEZA I \\ KARAKTERIZACIJA NANOVLAKANA POLI (VINIL ALKOHOL ) / PČELINJI VOSAK
}

Trenutno je primetno veliko interesovanje za korišćenje biološki aktivnih prirodnih proizvoda za modifikaciju i funkcionalizaciju vlakana za proizvodnju antimikrobnog zaštitnog medicinskog tekstila. Jedna od oblasti odnosi se na mogućnost dobijanja elektrospun nanovlakana sa potencijalnim bioaktivnim svojstvima. Cilj ove studije bio je proizvodnja $i$ karakterizacija nanovlakana sa vodenim rastvorom od poli ( vinil alkohol (PVA) i pčelinjim voskom (BV). Da bi se ispitala mogućnost dobijanja nanovlakana, dodatak pčelinjeg voska vršio se u dva oblika - kao rastvor i mikroemulzija. Vosak ima bogat hemijski sastav, smešu proteina, vitamina, mikroelemenata, estra, masne kiseline, ugljene hidrate, lipide. Sam vosak vlaži kožu, pomaže u oporavku i lečenju spaljene kože, usporava starenje i ima antibakterijsko dejstvo .

Vlakna su proizvedena u laboratorijskim uslovima sa jednom mlaznicom spin-drav uređaja. Nanovlakna se tretiraju sa 9 \% PVA rastvorom i 2 \% (po težini) voska kao aditiv. Kao tampon za elektrospun nanovlakna koristi se termofiksirani medicinski netkani tekstil. Struktura nanofiber slojeva je ispitivana elektronskim mikroskopom - SEM i AFM. Izrada poli (vinil alkohola) netkanih podmetača od elektrospin polimernih rešenja, koja sadrže različite koncentracije katjonskih, anjonskih, amfoterni i nejonskih surfaktanata je komplikovan proces. Vrsta aditiva koja služi za funkcionalizaciju vlakana primenjuje se za elektroprovodnost, površinski pritisak $i$ viskozitet, te je stoga korišćena reološka metoda za kontrolu procesa. Svojstva elektrospun materijala, kao što su propustljivost vazduha, propustljivost vodene pare, masa i debljina, su se pokazala kao dobra. Prosečni prečnici proizvedenih vlakna su bili u opsegu 100-420 nm. Vodootporni nanofiber podmetači su dobijeni termalnim postupkom na $100^{\circ} \mathrm{C}$ tokom $12 \mathrm{~h}$. Ispitivanja pomoću FTIR pokazala su da PVA / BV nanovlakna su prisutna u stabilnom obliku.

Dalja istraživanja će se obavljati da se ispita pripremljeni dvoslojni materijal i da se odredi njihova biološka aktivnost i potencijalna upotreba kao malterijala za regeneraciju kože posle povreda.

Ključne reči: $P V A / B W$, nanofiber, proizvodnja, karakterizacija, vodootporan, biološka aktivnost.

Originalni naučni rad

Rad primljen: 18.02.2015.

Rad prihvaćen: 06.04.2015. 